\title{
Weathering Processes and Mechanisms Caused by Capillary Waters and Pigeon Droppings on Porous Limestones
}

\author{
David Benavente $^{1, * \mathbb{C}}$, Marli de Jongh ${ }^{2}$ and Juan Carlos Cañaveras ${ }^{1}$ \\ 1 Department of Earth and Environmental Sciences, University of Alicante, 03690 Alicante, Spain; \\ jc.canaveras@ua.es \\ 2 School of Geographical \& Earth Sciences, University of Glasgow, Glasgow G12 8QQ, UK; \\ m.de-jongh.1@research.gla.ac.uk \\ * Correspondence: david.benavente@ua.es; Tel./Fax: +34-96590-3737
}

Citation: Benavente, D.; de Jongh, M.; Cañaveras, J.C. Weathering Processes and Mechanisms Caused by Capillary Waters and Pigeon Droppings on Porous Limestones. Minerals 2021, 11, 18. https://dx.doi.org/10.3390/min 11010018

Received: 23 November 2020 Accepted: 23 December 2020 Published: 25 December 2020

Publisher's Note: MDPI stays neutral with regard to jurisdictional claims in published maps and institutional affiliations.

Copyright: () 2020 by the authors. Licensee MDPI, Basel, Switzerland. This article is an open access article distributed under the terms and conditions of the Creative Commons Attribution (CC BY) license (https: / / creativecommons.org/ licenses/by/4.0/).

\begin{abstract}
This investigation studies the physical and chemical effect of salt weathering on biocalcarenites and biocalcrudites in the Basilica of Our Lady of Succour (Aspe, Spain). Weathering patterns are the result of salty rising capillary water and water lixiviated from pigeon droppings. Surface modifications and features induced by material loss are observable in the monument. Formation of gypsum, hexahydrite, halite, aphthitalite and arcanite is associated with rising capillary water, and niter, hydroxyapatite, brushite, struvite, weddellite, oxammite and halite with pigeon droppings. Humberstonite is related to the interaction of both types of waters. Analysis of crystal shapes reveals different saturation degree conditions. Single salts show non-equilibrium shapes, implying higher crystallisation pressures. Single salts have undergone dissolution and/or dehydration processes enhancing the deterioration process, particularly in the presence of magnesium sulphate. Double salts (humberstonite) have crystals corresponding to near-equilibrium form, implying lower crystallisation pressures. This geochemical study suggests salts precipitate via incongruent reactions rather than congruent precipitation, where hexahydrite is the precursor and limiting reactant of humberstonite. Chemical dissolution of limestone is driven mainly by the presence of acidic water lixiviated from pigeon droppings and is a critical weathering process affecting the most valuable architectural elements present in the façades.
\end{abstract}

Keywords: salt crystallisation; pigeon droppings; rising damp; stone conservation; calcarenite

\section{Introduction}

Limestones have been widely used as building materials in modern and historic construction and cultural heritage objects. Limestones can undergo severe weathering through complex chemical, mechanical and biological processes operating both sequentially and synergistically [1]. Weathering deterioration processes include crust formation, physical stress due to wetting and drying, freeze-thaw cycles, thermal expansion, salt crystallisation, dissolution and leaching [2-7]. These processes can act simultaneously and with one another in many different weathering regimes [8-10]; that is, some processes may dominate one part of a building, whilst other areas may be more sheltered and prone to other processes [11]. Weathering of carbonate rock results in a wide variety of stone deterioration patterns and products (pathologies) that influence the aesthetic and geotechnical properties of the stone [12].

Porous granular limestones are a traditional building material worldwide and probably constitute the most important stone resource as a building material in the architectural heritage of the coastal cities of the southwestern Mediterranean region [13]. Porous granular limestones do not decay in a steady, predictable pattern in response to slow dissolution. Instead, these stones, especially when used in construction in polluted environments, invariably decay episodically through physical breakdown $[14,15]$. These limestones, al- 
though usually homogeneous in their chemical characteristics, can show extreme variability across physical characteristics including hardness, fossil content and porosity [11].

Crystallisation of soluble salts within the pores of the stone has been recognized as the main weathering process responsible for the deterioration of exposed ornamental and building limestones [16-21]. Several factors influence salt crystallisation damage in porous materials such as granular limestones: pore size and porosity; nature of salts present; the ease with which salts achieve high saturation by evaporation; variations in environmental temperature; the energy difference between the salt crystal and the pore wall; the transport of the solution, in terms of the supply rate of the solution and the evaporation of water; and finally, stone strength - that is, the material's resistance to crystallisation pressure [22]

Salts found in building materials have a variety of sources including: deposition from the atmosphere due to both natural and anthropogenic air pollutants; sea salt particles; de-icing salts; and salts found in groundwater [23]. Salt crystallisation by rising damp is a major cause of damage to historic masonry as seen in the Tower of London or historic buildings of Venice [24]. Water in the building environment comes from a diverse range of sources including nearby seawater, rivers, aquifers, etc. In porous building materials, such as stones and mortars, rising damp occurs via capillary transport of water from the water table level. Salts are precipitated and crystallised at different heights on the stone façade in a sequence according to the salts' solubility and environmental temperature and relative humidity [23,25-27].

While bird droppings unquestionably impact the integrity of building stone, normal accumulations of bird droppings are considered only a marginal salt source $[1,25,28-32]$. However, bird's urine and excreta are a primary source of soluble salts and uric acid. Previous experiments have demonstrated that bird-related stone damage (staining, deposits) occurs within the first weeks of deposition [33]. After this time period, the majority of individual droppings have either: dissolved; desiccated to such a degree that they have rolled off; become colonized by microorganisms; or leached salts from the excreta. When pigeon excreta is dissolved by rain, the salt crystals are redeposited and may form white staining [31]. As well as impacting the aesthetic of the building, pigeon excreta has an acidic composition [34], enhancing the decay of limestone through chemical weathering processes.

In this paper, weathering processes of porous granular limestones from the Basilica of Our Lady of Succour (Aspe, SE Spain) are studied, and samples are considered representative of salt weathering processes leading to deterioration of stone across the entire building. The investigation studies how the physical and chemical effects of salt weathering impact limestone deterioration. Moreover, weathering patterns present in the monument are discussed in relation to the limestone's petrological and petrophysical properties. The investigation focuses on rising capillary water and water lixiviated from pigeon droppings-two of the most common and damaging types of waters known to cause stone deterioration in the built heritage.

\section{Materials and Methods}

\subsection{Rocks and Distribution in the Monument}

The Basilica of Our Lady of Succour (also known as Our Lady of Help) is a large building in Aspe (SE Spain) covering an area of more than $1650 \mathrm{~m}^{2}$ and is catalogued as a monument of cultural interest. It was designed in 1602 by Frençesc Verde, a well-known Genoese architect, and was built between the 17th and 18th centuries. The monument has three portals with saint figures in Baroque style. The principal façade is well-ornamented and contains figures of Our Lady of Succour and Saint Paul and Saint Peter supported by two baroque columns. Lateral façades have portals dedicated to Saint Teresa and Saint John the Baptist.

The main building stones used in the Basilica are porous limestones that consist of cream-coloured biocalcarenites and whitish biocalcirudites (Figure 1). These limestones were extracted from the quarry in the Sierra de la Madera $\left(38^{\circ} 17^{\prime} 12^{\prime \prime} \mathrm{N}, 0^{\circ} 48^{\prime} 47^{\prime \prime} \mathrm{W}\right)$, 
located north of the easternmost part of Sierra de Crevillente (Alicante SE Spain). Most of the sedimentary formations in this sierra are part of the Postorogenic Neogene Basins domain (Subbetic zone, Betic Cordillera) [35]. The limestones extracted from Sierra de la Madera belong to the Calizas de El Castellá Unit and consist of Upper Serravalian bioclastic limestones.
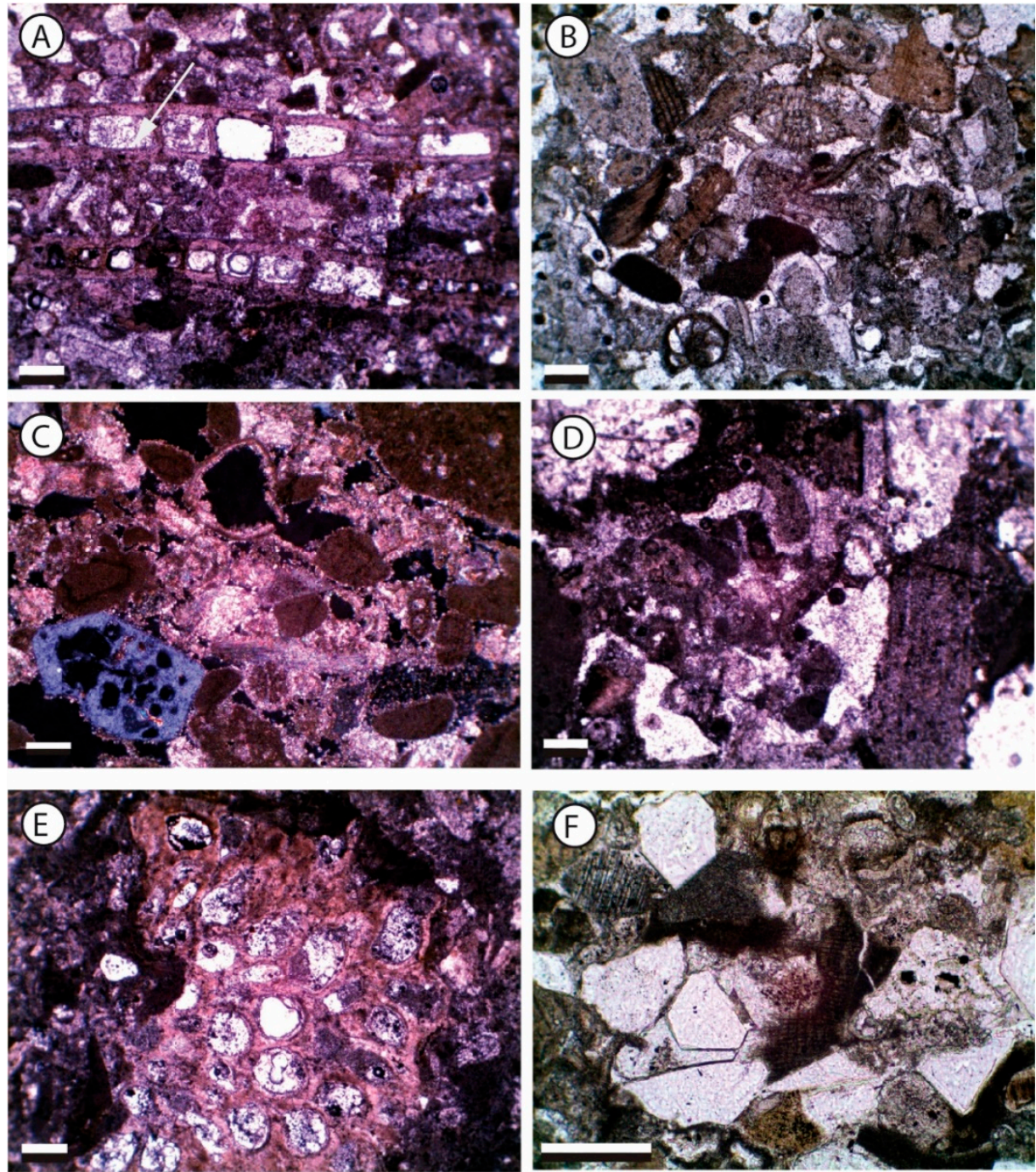

Figure 1. Thin section images of the 6 studied limestones: (A) Fine-grained biocalcarenite (f-CA) showing a poorly-sorted, grain-supported texture. Bioclasts consist mainly of benthic foraminifers, red algae and echinoderms. Extraclasts are mainly monocrystalline quartz grains. Secondary porosity is mainly moldic and intergranular; (B) Medium-grained biocalcarenite (m-CA) showing a grain-supported texture with moderate sorting. Clasts consist mainly of foraminifers (benthic and planktonic), red algae and echinoderm fragments, peloids and extraclasts (quartz); (C) Coarse-grained biocalcarenite (c-CA) composed of bioclasts (red algae, echinoderm, mollusc) and subeuhedral quartz grains (with anhydrite inclusions); (D) Dense biocalcirudite (d-CR) composed of mollusc, red algae and echinoderm fragments with a grain-supported poorly sorted texture; (E) Light biocalcirudite (l-CR). Detail of bryozoan fragment with intragranular (moldic) pores partly filled with calcite microcrystalline cement; and (F) Bateig biocalcarenite (b-CA) showing detrital quartz grains, dolomite crystals and bioclast fragments with calcite sintaxial and poikilotopic cements. Scale bar: $500 \mu \mathrm{m}$. (A-D,F) photomicrographs were taken under parallel nicols; (C) under crossed nicols.

The biocalcarenites (CA) can be subdivided based on grain size. Fine $(0.1-0.5 \mathrm{~mm})$ (f-CA), medium (0.1-1 mm) (m-CA) and coarse-grained $(0.2-2 \mathrm{~mm})(\mathrm{c}-\mathrm{CA})$ varieties were 
identified. CA samples have a cream colour, with a fossiliferous, grain-supported texture, with moderate to poor sorting. The porosity is high $(25-30 \%)$ and, therefore, stone density is medium-low. The principal rock components are: calcareous bioclasts, including benthic and planktonic foraminifers; bivalves; echinoderms and red algae. Locally, centimetrethick bivalve fragments are observed. The bioclast content is higher (80-85\%) in f-CA and $\mathrm{m}$-CA varieties and lesser in the c-CA variety (70\%). Most of the bioclasts are fragmented (re-worked) and are poorly sorted.

The most abundant accessory components of CA are monocrystalline and polycrystalline quartz grains ranging from 0.01 to $0.5 \mathrm{~mm}$ in size. Quartz grains often show anhydrite inclusions, indicating a Triassic origin. The micrite syngenetic matrix is sparse $(<5 \%)$ and the carbonate cement (LMC) mainly consists of microsparitic mosaic and syntaxial overgrowths. Pore types are interparticle, intraparticle and moldic. CA can be classified as a grainstone [36] or biosparite [37].

Biocalcirudites present two lithotypes, with different total porosity and cementation, referred to here as dense ( $\mathrm{d}-\mathrm{CR})$ and light (l-CR) biocalcirudites. $\mathrm{CR}$ samples have a whitish colour, with a fossiliferous, grain-supported, moderately to poorly sorted, detrital texture. The porosity is $5-10 \%$ and $15-20 \%$ in d-CR and $1-C R$ varieties, respectively. The bioclast content of $\mathrm{CR}$ is high $(\sim 85 \%)$, with a predominance of bivalves, red algae, echinoderms and foraminifers. Locally, centimetre-thick bivalve fragments are observed. Most of the bioclasts are fragmented (re-worked) and show evidence of micritization (especially red algae fragments). The grain size of bioclasts is highly variable, between $100 \mu \mathrm{m}$ and $3 \mathrm{~cm}$ (fragments of molluscs and encrusting red algae are the largest).

The most abundant accessory components of $C R$ are monocrystalline quartz grains ranging from 0.002 to $1 \mathrm{~mm}$ in size. Quartz grains often show anhydrite inclusion, indicating a Triassic origin. Lithic fragments (dolosparite) are also identified in the d-CR variety. As with CA, the micrite matrix is sparse $(<5 \%)$ in $1-C R$, but more abundant $(\sim 10 \%)$ in $\mathrm{d}-\mathrm{CR}$. The main pore types are interparticle, intraparticle and moldic. Microsparitic and syntaxial calcite cements are more abundant in d-CR. Both CR lithotypes can be classified as a packstone-grainstone [36], rudstone [38,39], fine to coarse calcirudite [37] or unsorted biosparrudite [37].

Limestone follows a regular distribution in three façades of the Basilica. The portals, the main saint figures (Our Lady of Succour, Saint Teresa and Saint John the Baptist) and the columns of the principal façade are made of a biocalcarenite (terms as b-CA) that is currently not found in the Sierra de la Madera's quarry. Other saint figures, including decorative elements and ornaments are composed of f-CA and m-CA. d-CR is also found in a few ashlars in the portals, covered by a protective patina. The most common limestone used in the ashlars of the façades is $\mathrm{m}-\mathrm{CA}$, whereas c-CA is relatively scarce in the building. $1-C R$ is found heavily altered.

b-CA is used in the construction of the most valuable architectural elements' higher value elements, including the columns of the principal façade and the main saint figures. $\mathrm{b}-\mathrm{CA}$ has a similar texture to $\mathrm{f}-\mathrm{CA}$ from the historical quarry. The colour of b-CA is slightly darker relative to f-CA and it does not present centimetric bivalves as occurs in the biocalcarenites of the historical quarry. Moreover, the amount of glauconite and terrigenous grains in b-CA is slightly higher than in CA.

These mineralogical and textural features that differentiate $b-C A$ and CA, however, are similar to the Bateig Stone. The origin of b-CA can be attributed to a missing lithostratigraphic unit or another quarry nearby the Basilica. The Bateig quarry located in Novelda $\left(38^{\circ} 24^{\prime} 17^{\prime \prime} \mathrm{N}, 0^{\circ} 48^{\prime} 02^{\prime \prime} \mathrm{W}\right)$, less than $10 \mathrm{~km}$ from the Basilica, may be the origin of b-CA. This stone has been widely used in the Spanish built heritage and presents similar mineralogical, textural and petrophysical properties to CA. The porosity of b-CA ranges from $20-25 \%$, the capillary coefficient $15-50 \mathrm{~g} / \mathrm{m}^{2} \cdot \mathrm{s}^{0.5}$ and compressive strength $35-45 \mathrm{MPa}[22,40,41]$. 
Overall, the limestones in the principal façades are covered by a reddish-cream protective patina composed of gypsum and iron oxides, which homogenized the colour and texture of present limestones.

\subsection{Petrophysical Properties}

Two types of samples were collected to perform all petrographic and petrophysical characterisation: (1) unaltered samples from the Basilica (f-CA, m-CA, c-CA, d-CR and l-CR as well as b-CA), for mineralogical, textural and pore structure characterisation; and (2) samples from the historical quarry of the Sierra de la Madera (f-CA, m-CA, c-CA, d-CR and 1-CR) for both mineralogical, textural and pore structure characterisation and also for petrophysical analysis, which requires a greater sample size for normalised standard tests.

Pore structure characterisation was described in terms of porosity and pore size distribution using mercury intrusion porosimetry (MIP) and helium pycnometry. Before characterisation of the porous rocks by MIP and helium pycnometry, rock specimens were cut into regular-sized samples of approximately $1 \mathrm{~cm}^{3}$ and were dried at $60{ }^{\circ} \mathrm{C}$ for $24 \mathrm{~h}$. Bulk density, $\rho_{b}\left(\mathrm{~g} / \mathrm{cm}^{3}\right)$, was determined as the ratio of dry weight to the volume of the sample. Grain or real density, $\rho_{r}\left(\mathrm{~g} / \mathrm{cm}^{3}\right)$, was obtained using an Ultrapyc 1200e (Quantachrome Instruments, Boynton Beach, FL, USA) helium pycnometer. Total porosity, $P_{T}$, is the fraction of the volume of voids over the bulk material volume and is calculated from bulk and grain densities $\left(P_{T}=\left(1-\rho_{b} / \rho_{r}\right)\right)$. Connected porosity, $P_{C}$, and mean throatpore radius, $r_{M}$, were obtained from mercury intrusion porosimetry (MIP) measurements using a PoreMaster 60 GT (Quantachrome Instruments, Boynton Beach, FL, USA) mercury porosimeter detecting pores in the pore radius interval of $0.002-200 \mu \mathrm{m}$. Total porosity is also used to evaluate the big pore fraction that MIP cannot measure $(r>200 \mu \mathrm{m})$.

Whole rock properties were performed on samples from the historical quarry of the Sierra de la Madera and defined by means of rock strength and capillary transport properties. Rock strength was characterised with the uniaxial compressive, $\sigma_{C}$, test following the EN-1926 normative [42]. The capillary absorption coefficient, $C$, was determined using the standard method in accordance with UNE EN-1925 [43].

\subsection{Salt Sampling and Mineralogical Characterisation}

Salts are commonly found in limestones and can be considered the most aggressive stone decay mechanism in the Basilica. Stone decay associated with crystallisation/dissolution cycles of salts from rising capillary water and water lixiviated from pigeon droppings represents a serious conservation problem. This situation widely occurs in other monuments built with porous limestones. Thirty weathered rock samples were collected and analysed.

The mineralogical composition of salts was analysed by powder $X$-ray diffraction (XRD) on a Bruker D8-Advance (Middlesex County, MA, USA) diffractometer with mirror Goebel (non-planar samples) using the CuKa radiation, a setting of $40 \mathrm{kV}$ and $40 \mathrm{~mA}, 2 \theta$ : $3-60^{\circ}$, step size of $0.05^{\circ}$ and scan step of $3 \mathrm{~s}$. Data were collected and interpreted using the XPowder software package [44]. The qualitative search-matching procedure was based on the ICDD-PDF2 database.

Identification of salt forms and chemical analysis of elements associated with salts was performed using a HITACHI S-3000N (Chiyoda, Tokyo, Japan) variable pressure electron microscope, which can analyse uncoated non-conductive samples at low beam energies. Such conditions do not compromise the integrity of analysed hydrated salt samples. Basic microanalysis and chemical mapping was carried out using energy dispersive X-ray (SEMEDX) using a Bruker Xash 3001 (Middlesex County, MA, USA) X-ray detector working at $20 \mathrm{kV}$. Samples were not coated with a conductive element, allowing for better identification of the dispersive X-ray peaks, and more accurate chemical analysis. 


\subsection{Geochemical Modelling}

The geochemical reactions of dissolution-precipitation of single and double salts were modelled with PHREEQC code using 3.4.0 version [45]. PHREEQC calculates the saturation index, $S I$, as $S I=\log (I A P / K)$. IAP is the ion activity product and $K$ is the equilibrium constant. The saturation index determines whether the water is saturated (equilibrium, $S I=0$ ), undersaturated (mineral dissolution, $S I<0$ ), or supersaturated (mineral precipitation, $S I>0$ ) with respect to the given mineral or phase. We consider that the theoretical initial solution can be reached by niter, halite and hexahydrite dissolution using the methodology described in [46]. The logarithm of the equilibrium constant, $\log K$, for niter, halite, hexahydrite and humberstonite are, $-0.1115,1.5845,-1.5651$ and -7.9259 , respectively $[47,48]$.

\section{Results and Discussion}

\subsection{Petrophysical Properties of Limestones}

The unaltered limestones present a complex porous media, with wide-ranging porosity (Table 1) and pore size (Figure 2). They come from the Basilica as well as from the Sierra de la Madera quarry and present various pore types that describe different petrophysical and durability properties of limestones. The studied limestones have abundant interparticle porosity whereas bioclasts exhibit intraparticle and moldic porosity.

Connected porosity of the CA is high and pore size distribution of CA reflects the relatively large grain size of bioclasts. The pore size distribution fits to a bimodal distribution.

CRs lithotypes present different microstructure features. d-CR is well-cemented and shows lower porosity values in comparison to l-CR. There is a wide pore size distribution due to grain size variations between the calcite grain matrix and bioclasts, reflecting the poorly sorted texture of the limestone.

Table 1 reveals that a fraction of the pore volume was not determined by the mercury intrusion porosimetry method (MIP). The porosity below $0.002 \mu \mathrm{m}$ can be considered negligible and the petrographic properties of the host-rock did not show a noticeable volume fraction of closed porosity. Consequently, the fraction of large pores is reflected in the total porosity values, which are always slightly higher than the connected porosity. These differences are important for rocks with coarse grain size (c-CA, d-CR and $1-C R)$.

Table 1. Connected porosity, $P_{C}$; total porosity, $P_{T}$; bulk density, $\rho_{b}$; capillary coefficient, $C$; and uniaxial compressive strength, $\sigma_{C}$, of the studied limestones: fine, f-CA, medium, m-CA, and coarse, c-CA, grained biocalcarenites, Bateig Stone, b-CA, and dense, d-CR, and light, l-CR biocalcirudites.

\begin{tabular}{ccccccc}
\hline Property & f-CA & m-CA & c-CA & b-CA & d-CR & l-CR \\
\hline$P_{C}(\%)$ & 27.60 & 28.06 & 26.68 & 18.65 & 8.18 & 21.60 \\
$P_{T}(\%)$ & 27.78 & 28.85 & 30.07 & 20.05 & 11.67 & 24.93 \\
$\rho_{b}\left(\mathrm{~g} / \mathrm{cm}^{3}\right)$ & 2.09 & 1.97 & 1.91 & 2.16 & 2.44 & 1.97 \\
$C\left(\mathrm{~g} / \mathrm{m}^{2} \cdot \mathrm{s}^{0.5}\right)$ & 104.19 & 180.26 & 436.42 & $15-50 *$ & 142.90 & 811.80 \\
$\sigma_{C}(\mathrm{MPa})$ & 17.11 & 15.18 & 12.17 & $35-45^{*}$ & 40.67 & 10.32 \\
\hline
\end{tabular}

* Capillary coefficient and compressive strength ranges for Bateig Stone [22,40,41].

Most of the studied porous building limestones have high values of connected porosity and present a main pore family in the range of 0.1 to $10 \mu \mathrm{m}$ (Figure 2). As a consequence, its pore structure is prone to capillary rise and salt weathering [49,50].

Capillary movement is critical in the Basilica because it transports saline waters from the bottom of the monument (water table level and rainwater) and water lixiviated from pigeon droppings in the portals. High water capillarity absorption rates occur mainly in the pore size range between $1 \mu \mathrm{m}$ and $1 \mathrm{~mm}$ and capillary heights become important as pore size decreases $(0.1-1 \mu \mathrm{m})$. The capillarity absorption rate is quantified with the capillary coefficient and reaches higher values for l-CR and c-CA (porous limestones with large pore fraction). 



Figure 2. Mercury intrusion porosimetry (MIP) pore size distribution of studied biocalcarenites: (A) fine, f-CA, medium, $\mathrm{m}-\mathrm{CA}$, coarse, c-CA, grained, and Bateig, b-CA biocalcarenites and (B) dense, d-CR, and light, l-CR biocalcirudites.

Limestone susceptibility to salt weathering is closely related to pore structure and mechanical properties. Salt crystallisation is effective in the pore interval 0.1-10 $\mu \mathrm{m}$. Salt requires considerable supersaturation to enter the pore fraction below $0.1 \mu \mathrm{m}$, conditions which are unlikely in the built environment. Moreover, salts can percolate through large pores $(>10 \mu \mathrm{m})$ without generating significant levels of crystallisation pressure on pore walls. The effectiveness of the crystallisation pressure in the material also depends on the rock strength, which can be considered to be the material's resistance to the mechanical action of salt crystallisation.

The studied limestones present a very low-low resistance according to [51] (Table 1). Porosity also has a strong influence on limestone strength. For example, d-CR is the most durable limestone in the Basilica as it presents the lowest porosity values and consequently highest compressive strength.

Previously, we found that the limestone of the main saint figures of the portals (Our Lady of Succour, Saint Teresa and Saint John the Baptist) and the columns of the principal façade are made using a biocalcarenite that might be attributed to b-CA. The mechanical properties of b-CA are slightly better than the other limestones used in the construction of the Basilica, although their aesthetic and textural properties are similar. This fact explains its excellent conservation state and perhaps why it was selected in the construction of these important elements in the portals.

\subsection{Decay Patterns by Inorganic Salt from Ramping Damp Waters}

In general, the stone of the monument is in excellent condition, although ashlars of the lower parts of façades and ornamental elements have been subject to weathering and subsequent deterioration. Two main deterioration patterns are observable to the naked eye and have been recognized in the Basilica: surface modifications (efflorescences, crust and deposits) and features induced by material loss (scaling, granular disintegration and alveolarization). The main, or more active deterioration agents are rising capillary water and water lixiviated from pigeon droppings in the portals (Figure 3).

The main alteration pattern in the ashlars of the lower parts of the façades is the loss of material through granular disintegration and alveolarization with efflorescence. The efflorescence consists of a whitish 1-3 mm thick microcrystalline layer which is more or less hardened, discontinuously covering the ashlars. Subflorescence is also visible where the stone layer above has detached through scaling. As previously discussed, l-CR at the site is highly altered due to its low mechanical strength and pore structure, making it susceptible to stone deterioration. m-CA also displays variable degrees of alteration, mainly due to its active pore structure, which makes it vulnerable to salt crystallisation. Some ashlars of m-CA show differential erosion (relief formation) due to textural heterogeneity, where the 
most porous, soft rock zones undergo relatively higher rates of material loss in comparison to compact rock zones (less porous and hard zones), which remain unaltered (Figure 3). Turkington and Smith [52] argue that spatial differentiation of decay at the level of individual blocks may initially be controlled by small-scale variability in key rock properties, most notably the degree of induration, texture and associated porosity/permeability. At the façade scale, however, localized environmental controls on processes such as surface soiling and crust formation may have a greater influence on the spatial variability of decay.



Figure 3. Main deterioration patterns identified in the Basilica: features induced by material loss (granular disintegration, scaling, differential erosion and alveolarization) and surface modifications (crusts, deposits and efflorescence).

In the upper parts of façades, meteoric water causes the dissolution of the cement, matrix and carbonate bioclasts of limestones, which causes the loss of cohesion leading to granular disintegration. The presence of meteoric water also encourages microbial colonization and development of biofilms and coloured biopatinas on the building. However, microbial colonization and biofilms are a relatively minor decay pattern in comparison to the efflorescence.

Pigeon droppings mostly affect the portals - the most valuable artistic and architectural elements in the façades, including the saint figures, decorative elements and ornaments. Pigeon droppings lead to crust formation and deposits and their lixiviated waters produce efflorescence and limestone dissolution.

The damage due to salt crystallisation by rising damp in the Basilica occurs in the lower parts of the three façades, being more intense in the Saint John the Baptist façade. Moreover, the Saint John the Baptist façade is exposed to more severe climatic variations in term of sun and wind exposure.

The mineralogy of salts shows both a strong vertical and horizontal variability and presents an inorganic nature (Table 2). The analysis was performed using XRD and SEM of the weathered material and shows the presence of mainly chlorides (halite), sulphates (gypsum, hexahydrite and aphthitalite), nitrates (niter) and sulfate nitrates (humberstonite) (Figures 4 and 5). Minor amounts of arcanite were also identified using SEM.

Table 2 shows the characterised mineral phases, whereas other polymorphs, metastable phases and possible hydrated phases were not detected. Minerals found in the XRD and SEM characterisation reflect the minerals in the building, but not necessarily the mineral phases and reactions involved in their formation prior to observed final mineral associations. We must consider these salts as representative of each salt system. For example, the 
presence of hexahydrite may imply the presence of epsomite. Consequently, we cannot assert which salt in each system is responsible for major damaging effects.

The microstructure of the porous limestones favour the capillary transport of salts and the effectiveness of salt crystallisation, explaining the rapid and severe damage due to salt crystallisation by rising damp. Moreover, the nature of the salts is also a key factor in stone deterioration. Certain salts, most notably sodium and magnesium sulphate, are consistently effective at salt weathering, whereas nitrate is relatively less effective, and two of the most common salts in the environment, calcium sulphate and sodium chloride appear to be relatively ineffective [1].

Table 2. Group, mineral name and chemical formula of salts found in the monument using XRD.

\begin{tabular}{ccc}
\hline Group & Mineral Name & Chemical Formula \\
\hline \multirow{4}{*}{ Sulphates } & arcanite & $\mathrm{K}_{2} \mathrm{SO}_{4}$ \\
& aphthitalite & $\mathrm{K}_{3} \mathrm{Na}_{2}\left(\mathrm{SO}_{4}\right)_{2}$ \\
gypsum & $\mathrm{CaSO}_{4} \cdot 2 \mathrm{H}_{2} \mathrm{O}$ \\
Sulfate nitrate & hexahydrite & $\mathrm{MgSO}_{4} \cdot 6 \mathrm{H}_{2} \mathrm{O}$ \\
Nitrates & humberstonite & $\mathrm{K}_{3} \mathrm{Na}_{7} \mathrm{Mg}_{2}\left(\mathrm{SO}_{4}\right)_{6}\left(\mathrm{NO}_{3}\right)_{2} \cdot 6 \mathrm{H}_{2} \mathrm{O}$ \\
Chlorides & niter & $\mathrm{KNO}_{3}$ \\
& halite & $\mathrm{NaCl}^{-}$ \\
Phosphates & brushite & $\mathrm{CaHPO}_{4} \cdot 2 \mathrm{H}_{2} \mathrm{O}$ \\
& estruvite & $\left(\mathrm{NH}_{4}\right) \mathrm{MgPO}_{4} \cdot 6\left(\mathrm{H}_{2} \mathrm{O}\right)$ \\
& hydroxyapatite & $\mathrm{Ca}_{5}\left(\mathrm{PO}_{4}\right)_{3}(\mathrm{OH})$ \\
Oxalates & oxammite & $\left(\mathrm{NH}_{4}\right)_{2} \mathrm{C}_{2} \mathrm{O}_{4} \cdot \mathrm{H}_{2} \mathrm{O}$ \\
& weddellite & $\mathrm{CaC}_{2} \mathrm{O}_{4} \cdot 2 \mathrm{H}_{2} \mathrm{O}$ \\
\hline
\end{tabular}

* Detected under SEM-mapping.
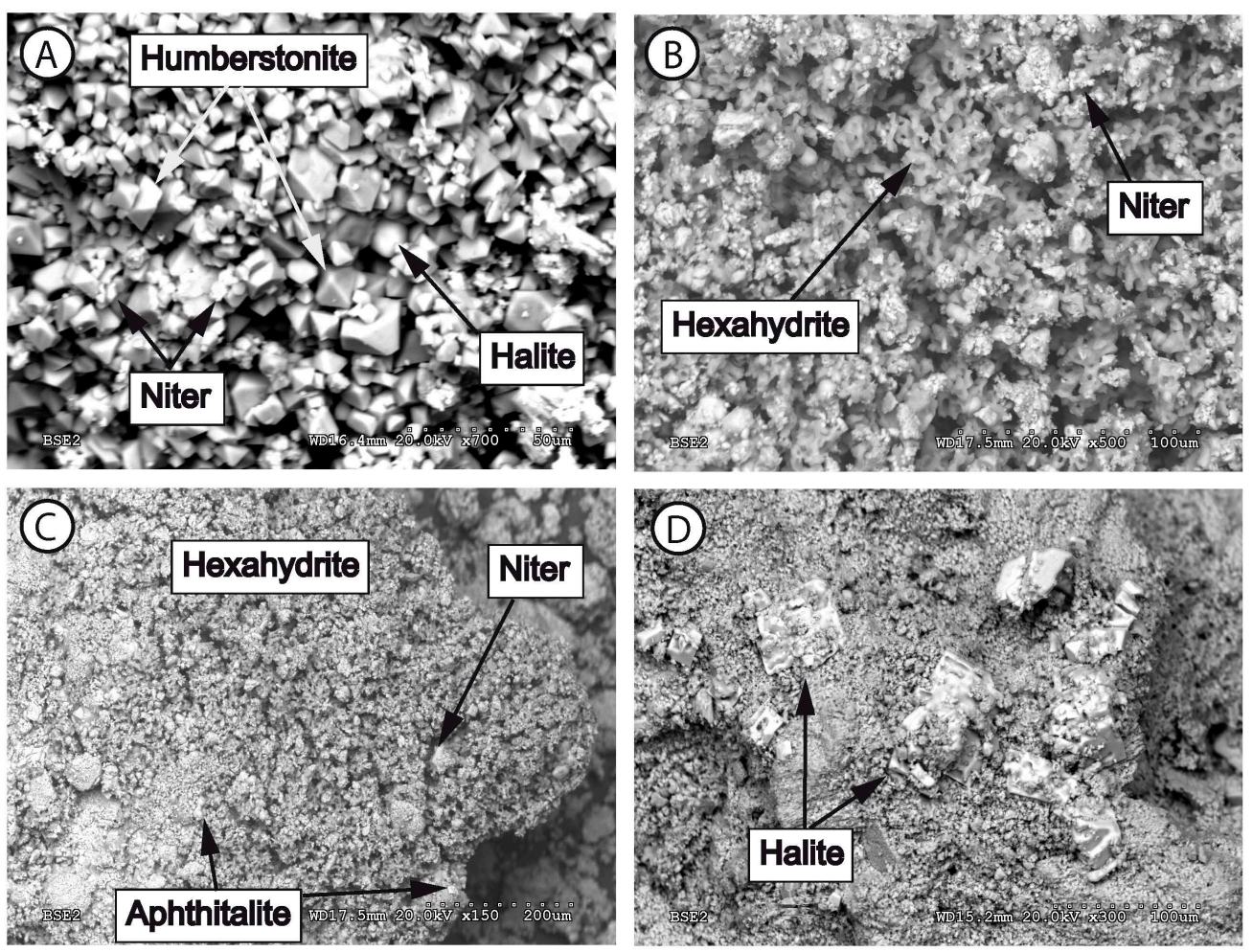

Figure 4. SEM microphotographs of salt forms from rising capillary waters: the isometric shape of humberstonite (A); needle-like crystals of niter (A); dissolution shapes of niter (B,C), aphthitalite, and halite (A,D); and dissolution and/or dehydration forms of hexahydrite $(\mathbf{B}, \mathbf{C})$. 



Figure 5. SEM image and energy dispersive X-ray (SEM-EDX) distribution map (mapping) showing the Na-K-Mg-S association (humberstonite). K displays a slight pattern distribution compared to Na-Mg-S due to the presence of niter ( $\mathrm{N}$ cannot be properly detected under SEM-EDX) whereas Ca can be attributed to calcite (rock host).

\subsection{Decay Patterns by Lixiviated Waters from Pigeon Droppings}

Pigeon excreta accumulates on the ground near the ashlars of the lower part of the façades and ornamental elements. Rainwater dissolves the excreta, creating salty, acidic lixiviated water. The interaction between lixiviated water and limestone leads to efflorescence deposits comprising phosphates (hydroxyapatite, brushite and struvite), nitrates (niter), oxalates (weddellite and oxammite) and chlorides (halite) (Table 2) (Figures 6 and 7).

These mineral associations are in concordance with previous studies [31,33]. Both rising capillary water and water lixiviated from pigeon droppings react and form double salts. Thus, the sulfate nitrate humberstonite is a double salt where nitrate ions come from lixiviated waters of droppings while sulphates come from rising capillary waters.

Pigeon droppings irreversibly affect the most valuable artistic and architectural elements in the façades (Figure 3). The droppings create crusts and deposits and their lixiviated water leads to efflorescence and limestone dissolution. These decay patterns result in aesthetic variation of the original colour that, although it does not induce changes in the cohesion and durability of limestones, impacts the relief of the decorative elements, ornaments and saint figures.

Microbial colonies attached to surfaces are often in close proximity to pigeon droppings. Under SEM, several organic compounds are recognized (Figure 6), including biofilms composed of filamentous microorganisms, spheroidal cell aggregates and extracellular polymeric substances (EPS). Biofilms normally initiate biocorrosion or participate in inorganic alteration processes by providing a locally lower $\mathrm{pH}$ and a concentration of oxygen and microbial metabolites $[10,53]$. In these microenvironments (biopatinas, lixiviated pigeon excreta deposits, etc.), microbial colonies commonly influence or induce mineralization. 

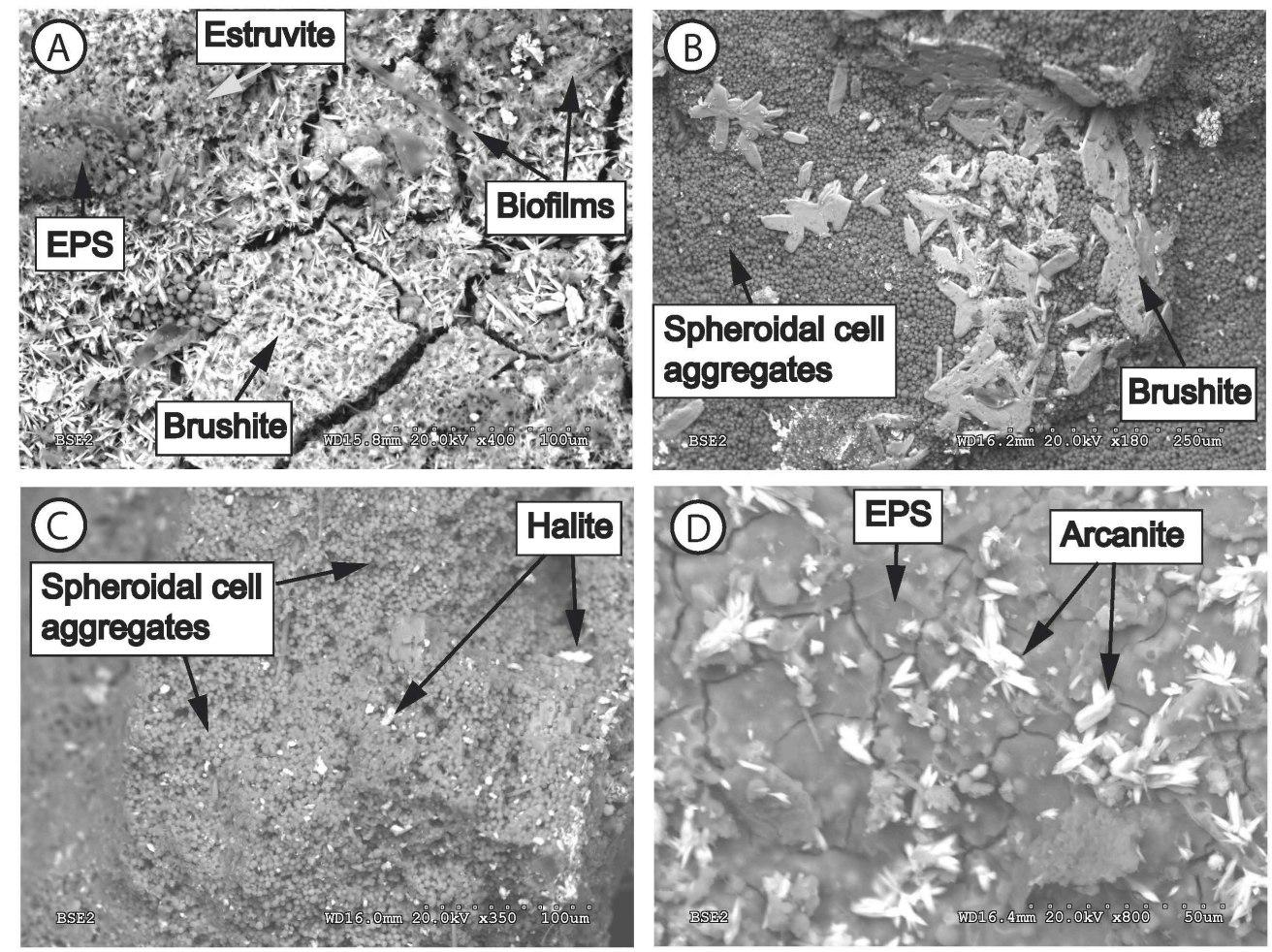

Figure 6. SEM microphotographs of phosphates (brushite and struvite) present needle-like (A) and massive (B) crystals. Halite (C) and arcanite (D) present needle-like crystals. Salts precipitate over biofilms composed of: filamentous microorganisms, spheroidal cell aggregates and extracellular polymeric substances (EPS).
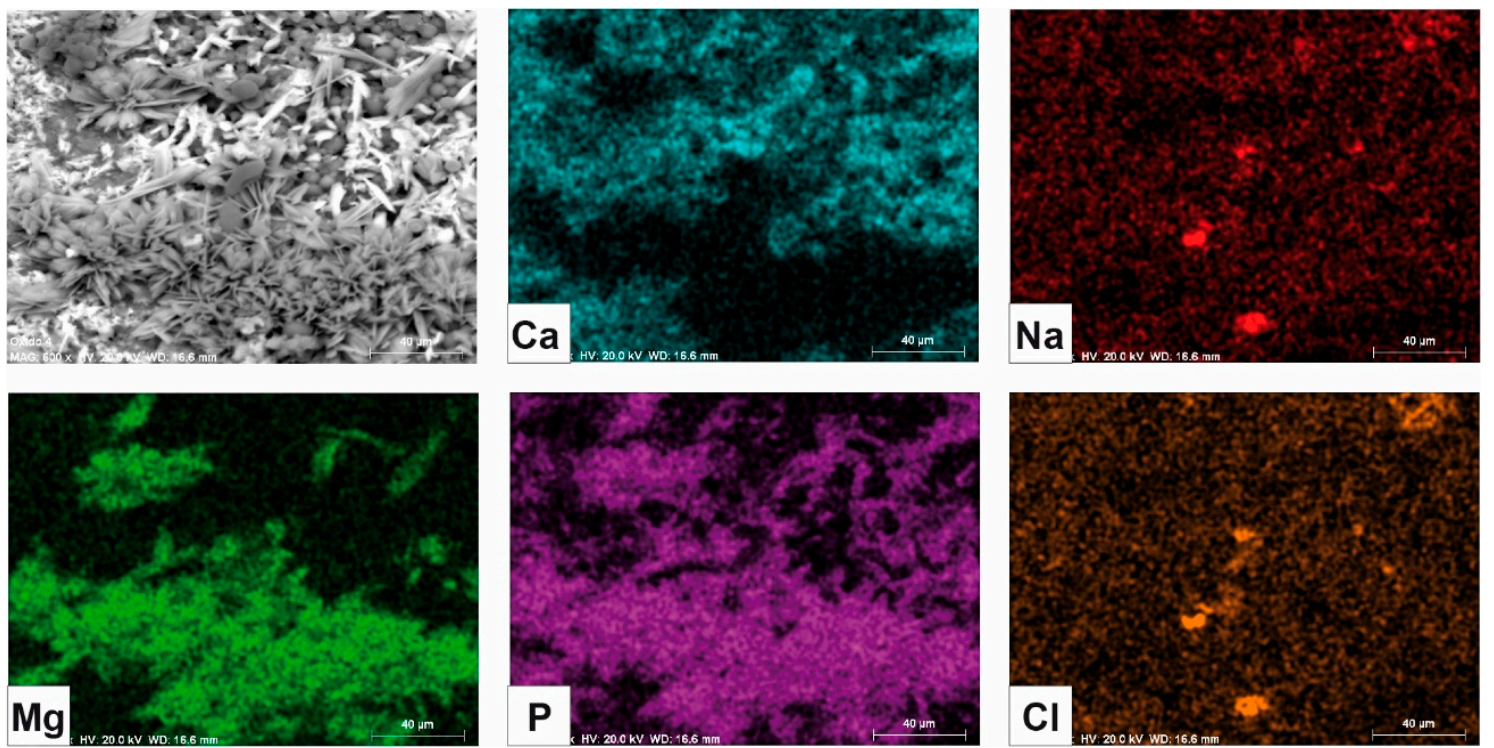

Figure 7. SEM image and SEM-EDX element distribution map showing different associations, including $\mathrm{Na}-\mathrm{Cl}$ (halite), $\mathrm{Ca}-\mathrm{P}$ (hydroxyapatite and brushite) and Mg-P (struvite, where $\mathrm{N}$ from ammonium ion cannot be properly detected under SEM-EDX).

Limestone weathering caused by pigeon droppings can be understood as a combination of physical (crystallisation pressure of soluble salts) and chemical (acid and salt-enhanced dissolution) processes. There is feedback between both decay mechanisms. 
Chemical dissolution is critical in the decay process of studied limestones. Calcite, present in both rock matrix and cement, provides rock cohesion and is more soluble than carbonate grains (bioclasts) due to its micron and sub-micron grain size. Calcite dissolution is largely responsible for decreasing cohesion and progressive disintegration (sanding) [54] Gomez-Heras et al. [31] reported that the water lixiviated from pigeon droppings can reach $\mathrm{pH}$ values of 4.5 . Under these acid conditions, lixiviated water can lead to grain dissolution-generating new pores and fissures. Importantly, the pore structure of b$\mathrm{CA}$ and $\mathrm{f}-\mathrm{CA}$ is active, and so capillary processes can transport acid waters from the rock surface to several millimetres' depth. SEM observations and SEM-EDX analysis of phosphorus and sulphate revealed that lixiviated water can penetrate $3 \mathrm{~cm}$ into a sample taken from an ashlar in the Saint Teresa portal.

Bird droppings are a potential source of a wide range of soluble salts and uric acid. As a result, droppings can lead to salt crystallisation and stone deterioration and should therefore be considered an important factor in understanding how limestones decay over time [55]. Pigeon droppings generate solutions with low $\mathrm{pH}$ and high salinity $(4 \%$ of soluble salts) when they are leached by water [31]. This is contrary to the traditional view in which pigeon droppings are thought to have a limited impact on the decay of building stones, generating only phosphates and/or nitrates on the surface $[31,56]$.

\subsection{Geochemical Model of the Salt Assemblage}

As we previously described, the mineralogy of salts shows both a strong vertical and horizontal variability. Different precipitation sequences are observed in the vertical profile, where the more soluble salts are located at higher heights of the walls and columns. These conditions produce different mineral morphologies, which range from isometric shapes to needle-like crystals. Single salts, in general, show non-equilibrium shapes although they have undergone dissolution and/or dehydration processes.

Halite clearly displays the dissolution forms of cubic and hopper-type morphologies (Figure 4A,D). Niter and halite present dissolution forms due to their high solubility and hygroscopic features. Cycles of condensation and evaporation with subsequent cycles of dissolution/crystallisation of salts in the porous system cause damage to the porous rocks. Salts can crystallise only when the ambient relative humidity is lower than the equilibrium relative humidity of the saturated salt solution. The equilibrium relative humidity is nearly independent of both temperature and the presence of other salt species [46]. These types of salts, and in particular halite, are the most common salts found in buildings. These common salts readily crystallise and do not reach high supersaturation ratios before crystallising in porous materials [17]. This explains the relatively lesser risk posed by halite in the built heritage [46]. Moreover, in salt mixtures or multicomponent solutions, damage by salt weathering is less aggressive than in single salts, although the critical relative humidity for phase transitions is not greatly influenced by the presence of other salt species [46].

Aphthitalite is less abundant than the other observed salts. It also presents dissolution forms and is associated with niter and hexahydrite. Hexahydrite shows dehydration forms (Figure 4B,C). Dissolution-recrystallisation cycles of magnesium sulphates such as epsomite $\left(\mathrm{MgSO}_{4} \cdot 7 \mathrm{H}_{2} \mathrm{O}\right)$ and hexahydrite $\left(\mathrm{MgSO}_{4} \cdot 6 \mathrm{H}_{2} \mathrm{O}\right)$ can be triggered by humidity cycling at very high relative humidity and, more likely, by rainfall and subsequent drying. The precipitation of magnesium sulphate salts and, especially, the rehydration of the lower hydrated phases under conditions of confinement within a porous material can produce substantial stress [46,47].

Salts associated with the water lixiviated from droppings present morphologies suggesting fast-growing mechanisms (Figures 6 and 7) [57]. Geochemical reactions between the salty and acidic lixiviated water and limestones lead to moderate to high supersaturation degrees. Thus, phosphates present massive and needle-like crystals (Figure 6A,B and Figure 7) and arcanite and halite present needle-like crystals over EPS (Figure 6C,D). Tabular oxalate crystals are also found, but are less abundant than the other salts. 
Double salts, mainly humberstonite, have crystal forms corresponding to near-equilibrium form, implying slow crystal growth. Figures 4 and 5 reveal the isometric shape of the humberstonite in the analysed samples. Humberstonite was found to be associated with halite and niter and placed between and/or over them. However, hexahydrite is absent in this mineral assemblage. The near-equilibrium crystal shape suggests they precipitate via incongruent reactions rather than congruent precipitation. Under these dissolutionprecipitation conditions, hexahydrite seems to be the precursor and limiting reactant of humberstonite.

As a first approximation, we consider the theoretical initial solution is obtained by niter, halite and hexahydrite dissolution. The resulting solution is highly supersaturated $(S I=7.25)$ in humberstonite, so congruent precipitation will show a non-equilibrium shape.

The effectiveness of salt crystallisation depends on the pore size interval, while the crystallisation pressure that each salt exerts on the pore wall is determined by the supersaturation degree that the salt can reach [46]. Single salts, mainly halite and niter, present non-equilibrium shapes, such as needle-like crystals (Figure 2A). This indicates salt precipitation is produced under a high supersaturation degree [17] and, therefore, yields high crystallisation pressures on the pore wall. Contrarily, double salts show a near-equilibrium crystal shape [57], which suggests they produce relatively lower crystallisation pressures on the pore wall.

\section{Conclusions}

In this paper, we investigated the physical and chemical processes associated with salt weathering of granular limestones found in the built heritage. Particularly, we focused on the impact of rising capillary water and salty, acidic water lixiviated from pigeon droppings; two of the most common sources of decay in the built heritage. Although the conservation state of the monument is excellent, identified weathering patterns have been shown here to impact the petrological and petrophysical properties of granular limestones. 1-CR is found highly altered due to its low mechanical strength and high porosity. Contrary to this, $\mathrm{d}-\mathrm{CR}$ is considered the most durable limestone in the Basilica due to its relatively high compressive strength and low porosity. $\mathrm{m}-\mathrm{CA}$ is the most abundant biocalcarenite facie in the monument, and also displays variable degrees of alteration due mainly to its active pore network and susceptibility to salt crystallisation.

The most aggressive decay mechanism on site is salt crystallisation-the severity of which depends on the supersaturation degree that can be reached by individual salts present. Analysis of crystal shapes reveals the saturation degree of the salts and therefore the stress they can exert on the porous limestone. Furthermore, analysis of crystal shapes also provides insight into the geochemical processes that occur through capillary rising of saline water and the lixiviated water of droppings. Single salts in general show nonequilibrium shapes, implying higher crystallisation pressure that each salt exerts on the pore wall. Moreover, single salts have undergone dissolution and/or dehydration processes. Cycles of evaporation and condensation (or water absorption from rain or capillary water) induce a repetitive cycle of salt dissolution/crystallisation in the porous media, leading to decay of limestone. These processes can modify the porosity and the pore size distribution of stones, reducing their mechanical strength as well.

The dissolution/crystallisation process is notably critical in the presence of magnesium sulphate, compared to other salts found such as niter or halite. Contrarily, double salts have crystal forms corresponding to near-equilibrium forms via incongruent reactions, implying a slow crystal growth and lower crystallisation pressures.

Chemical weathering of limestones is less aggressive compared to the physical weathering associated with salt crystallisation. However, chemical dissolution of limestone, driven by the presence of acidic water lixiviated from pigeon droppings, is critical because it affects the most valuable architectural elements present in the façades. The presence of other salts and atmospheric $\mathrm{CO}_{2}$ dissolved in the pore waters can also enhance the 
dissolution of the calcite fraction of limestones, reducing cohesion and impacting stone durability.

Author Contributions: Conceptualization, D.B. and J.C.C.; methodology, D.B. and J.C.C.; validation, D.B., M.d.J. and J.C.C.; formal analysis, D.B.; investigation, D.B.; resources, D.B.; data curation, D.B. and J.C.C.; writing—original draft preparation, D.B.; writing—review and editing, M.d.J.; visualization, M.d.J.; supervision, D.B.; project administration, D.B.; funding acquisition, D.B. All authors have read and agreed to the published version of the manuscript.

Funding: This research received no external funding.

Institutional Review Board Statement: Not applicable.

Informed Consent Statement: Not applicable.

Data Availability Statement: Not applicable.

Acknowledgments: We sincerely thank the Asociación de Amigos de la Basílica de Nuestra Señora del Socorro and Aspe City Council for their invaluable help and financial support. Authors give acknowledgement to the Regional Government of Madrid (Spain) (Top Heritage, grant number S2018/NMT-4372) and the Technical Research Services of the University of Alicante (SSTTI-UA) for the analyses performed using the equipment held at this institution, which was financed by the EU, MINECO and Generalitat Valenciana (State Programme for Knowledge Generation and Scientific and Technological Strengthening of the R+D+i System and P.O. FEDER 2007-2013 funds).

Conflicts of Interest: The authors declare no conflict of interest.

\section{References}

1. Goudie, A.S.; Viles, H.A. Salt Weathering; Wiley: Chichester, UK, 1997; 241p.

2. Sabbioni, C.; Brimblecombe, P.; Cassar, M. The Atlas of Climate Change Impact on European Cultural Heritage: Scientific Analysis and Management Strategies; Anthem Press: London, UK, 2010.

3. Charola, A.E. Salts in the deterioration of porous materials. An overview. JAIC J. Am. Inst. Conserv. 2000, 39, 327-343. [CrossRef]

4. Cassar, J. The use of limestone in a historic context-The experience of Malta. In Limestone in the Built Environment: Present-Day Challenges for the Preservation of the Past; Smith, B.J., Gomez-Heras, M., Viles, H.A., Cassar, J., Eds.; Geological Society, Special Publications: London, UK, 2010; Volume 331, pp. 13-25.

5. Siegesmund, S.; Snethlage, R. Stone in Architecture: Properties, Durability, 4th ed.; Springer: Berlin/Heidelberg, Germany, 2014.

6. Charola, A.E.; Bläuer, C. Salts in Masonry: An Overview of the Problem. Restor. Build. Monum. 2015, 21, 119-135. [CrossRef]

7. Grøntoft, T.; Cassar, J. An assessment of the contribution of air pollution to the weathering of limestone heritage in Malta. Environ. Earth Sci. 2020, 79. [CrossRef]

8. Nicholson, D.T. Pore properties as indicators of breakdown mechanisms in experimentally weathered limestones. Earth Surf. Process. Landf. 2001, 26, 819-838. [CrossRef]

9. Nasri, F.; Boumezbeur, A.; Benavente, D. Influence of the petrophysical and durability properties of carbonate rocks on the deterioration of historic constructions in Tebessa (northeastern Algeria). Bull. Int. Assoc. Eng. Geol. 2018, 78, 3969-3981. [CrossRef]

10. Sanchez-Moral, S.; Cañaveras, J.C.; Benavente, D.; Fernandez-Cortes, A.; Cuezva, S.; Elez, J.; Jurado, V.; Rogerio-Candelera, M.A.; Saiz-Jimenez, C. A study on the state of conservation of the Roman Necropolis of Carmona (Sevilla, Spain). J. Cult. Herit. 2018, 34, 185-197. [CrossRef]

11. Smith, B.J.; Viles, H.A. Rapid, catastrophic decay of building limestones: Thoughts on causes, effects and consequences. In Heritage Weathering and Conservation; Fort González, R., Alvarez de Buergo, M., Gómez-Heras, M., Vazquez-Calvo, C., Eds.; Taylor and Francis: London, UK, 2006; pp. 191-197.

12. ICOMOS-ISCS. Illustrated Glossary on Stone Deterioration Patterns. Available online: http://international.icomos.org/ publications/monuments_and_sites/15/pdf/Monuments_and_Sites_15_ISCS_Glossary_Stone.pdf (accessed on 12 December 2020).

13. Martinez-Martinez, J.; Benavente, D.; Jimenez Gutierrez, S.; Garcia del Cura, M.A.; Ordóñez, S. Stone weathering under Mediterranean semiarid climate in the fortress of Nueva Tabarca island (Spain). Build. Environ. 2017, 121, 262-276. [CrossRef]

14. Smith, B.J.; Gomez-Heras, M.; Mccabe, S. Understanding the decay of stone-built cultural heritage. Prog. Phys. Geogr. 2008, 32, 439-461. [CrossRef]

15. Martínez-Martínez, J.; Benavente, D.; Gomez-Heras, M.; Marco-Castaño, L.; Del Cura, M.; Ángeles, G. Non-linear decay of building stones during freeze-thaw weathering processes. Constr. Build. Mater. 2013, 38, 443-454. [CrossRef]

16. Benavente, D.; Garcia-Del-Cura, M.A.; Fort, R.; Ordóñez, S. Thermodynamic modelling of changes induced by salt pressure crystallisation in porous media of stone. J. Cryst. Growth 1999, 204, 168-178. [CrossRef]

17. Rodriguez-Navarro, C.; Dohene, E. Salt weathering: Influence of evaporation rate, supersaturation and crystallisation pattern. Earth Surf. Process. Landf. 1999, 24, 191-209. [CrossRef]

18. Scherer, G.W. Crystallization in pores. Cem. Concr. Res. 1999, 29, 1347-1358. [CrossRef] 
19. Flatt, R.J. Salt damage in porous materials: How high supersaturations are generated. J. Cryst. Growth 2002, $242,435-454$. [CrossRef]

20. Steiger, M. Crystal growth in porous materials-II: Influence of crystal size on the crystallization pressure. J. Cryst. Growth 2005, 282, 470-481. [CrossRef]

21. Espinosa-Marzal, R.M.; Scherer, G.W. Mechanisms of damage by salt crystallization. In Limestone in the Built Environment: Present-Day Challenges for the Preservation of the Past; Smith, B.J., Gomez-Heras, M., Viles, H.A., Cassar, J., Eds.; Special Publications, Geological Society of London: London, UK, 2010; Volume 331, pp. 61-77.

22. Benavente, D.; Cueto, N.; Martinez-Martinez, J.; Garcia-del-Cura, M.A.; Cañaveras, J.C. The influence of petrophysical properties on the salt weathering of porous building rocks. Environ. Geol. 2007, 52, 197-206. [CrossRef]

23. Steiger, M.; Charola, A.E.; Sterflinger, K. Weathering and Deterioration. In Stone in Architecture; Springer: Berlin/Heidelberg, Germany, 2011; pp. 227-316.

24. Arnold, A. Rising damp and saline minerals. In Proceedings of the 4th International Congress on the Deterioration and Preservation of Stone Objects; Gauri, K.L., Gwinn, J.A., Eds.; University of Louisville: Louisville, KY, USA, 1982.

25. Arnold, A.; Zehnder, K. Salt Weathering on monuments. In Conservation of Monuments in the Mediterranean Basin; Zezza, F., Ed.; Grafo, Brescia: Bari, Italy, 1990; pp. 31-58.

26. Lopez-Arce, P.; Doehne, E.; Greenshields, J.; Benavente, D.; Young, D. Treatment of rising damp and salt decay: The historic masonry buildings of Adelaide, South Australia. Mater. Struct. 2009, 41, 827-848. [CrossRef]

27. Ruiz-Agudo, E.; Mees, F.; Jacobs, P.; Rodriguez-Navarro, C. The role of saline solution properties on porous limestone salt weathering by magnesium and sodium sulfates. Environ. Geol. 2007, 52, 269-281. [CrossRef]

28. Schaffer, R.J. The Weathering of Natural Building Stones; Building Research: London, UK, 1932; 149p.

29. Bassi, M.; Chiatante, D. The role of pigeon excrement in stone biodeterioration. Int. Biodeterior. Bull. 1976, 12, 73-79.

30. Price, C.A. Stone Conservation-An Overview of Current Research; Research in Conservation Series; Getty Conservation Institute: Los Angeles, CA, USA, 1996.

31. Gómez-Heras, M.; Benavente, D.; Álvarez De Buergo, M.; Fort, R. Soluble salt minerals from pigeon droppings as potential contributors to the decay of stone based Cultural Heritage. Eur. J. Miner. 2004, 16, 505-509. [CrossRef]

32. Dyer, T.D. Deterioration of stone and concrete exposed to bird excreta-Examination of the role of glyoxylic acid. Int. Biodeterior. Biodegrad. 2017, 125, 125-141. [CrossRef]

33. Spennemann, D.H.R.; Pike, M.; Watson, M.J. The acidity of pigeon excreta and its implications for heritage conservation. Int. J. Build. Pathol. Adapt. 2017, 35, 2-25. [CrossRef]

34. Spennemann, D.H.; Watson, M.J. Dietary habits of urban pigeons (Columba livia) and implications of excreta $\mathrm{pH}-\mathrm{A}$ review. Eur. J. Ecol. 2017, 3, 27-41. [CrossRef]

35. Tent, J.E. La Estructura y Estratigrafía de las Sierras de Crevillente, Abanilla y Algayat: Su Relación Con la Falla de Crevillente. Ph.D. Thesis, Universidad de Alicante, España, Spain, 2003; 970p.

36. Dunham, R.J. Classification of carbonate rocks according to depositional texture. In Classification of Carbonate. Rocks-A Symposium; Ham, W.E., Ed.; American Association of Petroleum Geologists Mem: Tulsa, OK, USA, 1962; pp. 108-121.

37. Folk, R.L. Spectral subdivision of limestone types. In Classification of Carbonate Rocks-A Symposium; Ham, W.E., Ed.; American Association of Petroleum Geologists Mem: Tulsa, OK, USA, 1962; pp. 62-84.

38. Embry, A.F.; Klovan, J.E. A Late Devonian reef tract on Northeastern Banks Island. NWT Can. Pet. Geol. Bull. 1971, $19,730-781$.

39. Wright, V.P. A revised Classification of Limestones. Sediment. Geol. 1992, 76, 177-185. [CrossRef]

40. Benavente, D. Modelización y Estimación de la Durabilidad de Materiales Pétreos Porosos Frente a la Cristalización de Sales. Ph.D. Thesis, University of Alicante, 2003. Available online: http://www.cervantesvirtual.com/FichaObra.html?Ref=12011 (accessed on 29 March 2017). (In Spanish)

41. Benavente, D.; Pla, C.; Cueto, N.; Galvañ, S.; Martínez-Martínez, J.; García-Del-Cura, M.A.; Ordóñez, S. Predicting water permeability in sedimentary rocks from capillary imbibition and pore structure. Eng. Geol. 2015, 195, 301-311. [CrossRef]

42. UNE-EN 1926. Natural Stone Tests Methods. Determination of Uniaxial Compressive Strength; European Committee for Standardization: Bruxelles, Belgium, 2007.

43. UNE-EN 1925. Natural Stone Test Methods. Determination of Water Absorption Coefficient by Capillarity; European Committee for Standardization: Bruxelles, Belgium, 1999.

44. Martin Ramos, J.D. XPowder: A Software Package for Powder X-Ray Diffraction Analysis; Granada, Spain, 2004. Available online: http:/ / www.xpowder.com/ (accessed on 12 December 2020).

45. Parkhurst, D.L.; Appelo, C.A.J. Description of input and examples for PHREEQC version 3-A computer program for speciation, Batch-Reaction, One-Dimensional Transport, and Inverse Geochemical Calculations. In U.S. Geological Survey Techniques and Methods, Book 6, Chapter A43; US Geological Survey: Denver, CO, USA, 2013; p. 497.

46. Benavente, D.; Brimblecome, P.; Grossi, C.M. Thermodynamic calculations for the salt crystallisation damage in porous built heritage using PHREEQC. Environ. Earth Sci. 2015, 74, 2297-2313. [CrossRef]

47. Steiger, M.; Kiekbusch, J.; Nicolai, A. An improved model incorporating Pitzer's equations for calculation of thermodynamic properties of pore solutions implemented into an efficient program code. Constr. Build. Mater. 2008, 22, 1841-1850. [CrossRef] 
48. Steiger, M.; Linnow, K.; Ehrhardt, D.; Rohde, M. Decomposition reactions of magnesium sulfate hydrates and phase equilibria in the MgSO4-H2O and Na+-Mg2+-Cl-SO4 2-H2O systems with implications for Mars. Geochim. Cosmochim. Acta 2011, 75, 3600-3626. [CrossRef]

49. Benavente, D. Why pore size is important in the deterioration of porous stones used in the built heritage? Macla 2011, 15, 41-42.

50. Benavente, D.; Martinez-Martinez, J.; Cueto, N.; Ordonez, S.; Garcia-del-Cura, M.A. Impact of salt and frost weathering on the physical and durability properties of travertines and carbonate tufas used as building material. Environ. Earth Sci. 2018, 77, 147. [CrossRef]

51. Deere, D.U.; Miller, R.P. Engineering Classification and Index Properties for Intact Rock; Report AFWL-TR-65-116; Air Force Weapons Laboratory Technical: Millor; University of Illinois: Urbana, IL, USA, 1966.

52. Turkington, A.V.; Smith, B.J. Interpreting spatial complexity of decay features on a sandstone wall: St. Matthew's church, belfast. In Controls and Causes of Stone Decay; Smith, B.J., Turkington, A.V., Eds.; Donhead: London, UK, 2004; pp. 149-166.

53. Cañaveras, J.C.; Cuezva, S.; Sánchez-Moral, S.; Lario, J.; Laiz, L.; Gonzalez, J.M.; Saiz-Jimenez, C. On the origin of fiber calcite crystals in moonmilk deposits. Naturwissenschaften 2006, 93, 27-32. [CrossRef] [PubMed]

54. Benavente, D.; Sanchez-Moral, S.; Fernandez-Cortes, A.; Cañaveras, J.C.; Elez, J.; Saiz-Jimenez, C. Salt damage and microclimate in the Postumius Tomb, Roman Necropolis of Carmona, Spain. Environ. Earth Sci. 2011, 63, 1529-1543. [CrossRef]

55. Ali, H.E.; Khattab, S.I.; Al Mukhtar, A. The effect of biodeterioration by bird droppings on the degradation of stone built. Eng. Geol. Soc. Territ. 2015, 8, 515-520.

56. Alessandrini, G.; Colombo, C.; Toniolo, L.; Casadio, F. Analytical investigation of films and patinas on the Istria stone. In Protection and Conservation of the Cultural Heritage of the Mediterranean Cities; Galán, E., Zezza, F., Eds.; Balkema: Lisse, The Netherlands, 2002; pp. 79-83.

57. Sunagawa, I. Crystals Growth, Morphology and Perfection; Cambridge University Press: Cambridge, UK, 2005. 